Forthcoming in Marginalized Identities, Peripheral Theologies: Expanding Conversations in Analytic Theology, edited by Michelle Panchuk and Michael Rea (Oxford University Press). 3-6-2019 Draft, please do not cite without prior permission.

\title{
Toward an Analytic Theology of Liberation ${ }^{1}$ \\ Sameer Yadav \\ Westmont College \\ Santa Barbara, CA \\ syadav@westmont.edu
}

\section{Analytic Theology and Liberation Theology}

The open secret of analytic philosophy of religion since its 20 th century revival has been that it is for the most part a revival of philosophical theology, and particularly Christian philosophical theology. ${ }^{2}$ More recently, Christian analytic philosophers and theologians sympathetic to them have transformed this open secret into a research program by explicitly thematizing the use of analytic philosophical tools for the particular work of Christian theology. Dubbing this work as "analytic theology" (hereafter, AT) and editing an eponymous volume on the subject, ${ }^{3}$ Oliver Crisp and Michael Rea have succeeded in inaugurating AT as a distinct subregion in the philosophy of religion. Besides prompting a spate of first-rate philosophical work theorizing a variety of Christian theological commitments, the advent of AT has also prompted a good deal of meta-theological reflection: What kinds of theology are ruled out by the methodological commitments of AT? Is AT more conducive for certain conceptions of Christian theology than others? ${ }^{4}$

A casual glance at the AT literature would suggest that AT has been most conducive to generating traditional and orthodox Christian theology and least conducive to generating the revisionary projects of liberation theology (hereafter, LT). As William Wood observes, we can distinguish between the "formal model" of AT and its actual manifestation as a research program. Formally speaking,

${ }^{1}$ I would like to thank Michelle Panchuk, Michael Rea, and Kevin Timpe for helpful comments on an earlier draft of this paper.

${ }^{2}$ For a qualitative demographic study of the religious constituency of analytic philosophy of religion, see Helen de Cruz at http://prosblogion.ektopos.com/2013/12/31/results-of-myqualitative-studyof-attitudes-and-religious-motivations-of-philosophers-of-religion, as well as the PhilPapers survey conducted by David Bourget and David Chalmers at http://fragments.consc.net/djc/2010/11/morephilpapers-surveyresults.html. In William Wood's "Trajectories, Traditions, and Tools in Analytic Theology" Journal of Analytic Theology 4 (2016), Wood summarizes the data as follows: "On the best data that we have, approximately 70 percent of philosophers of religion are theists, and about 58 percent identify as Christians. By contrast, among philosophers in general, about 73 percent identify as atheists." (258, f.n. $8)$.

${ }^{3}$ Oliver D. Crisp and Michael C. Rea, eds., Analytic Theology: New Essays in the Philosophy of Theology (New York: Oxford University Press, 2009).

${ }^{4}$ This question is raised perhaps most strikingly and controversially by Randall Rauser's "Theology as a Bull Session," in Analytic Theology, eds. Crisp and Rea, wherein he suggests that analytic theology is a safeguard against "academic bullshit" in theology (71). However, the task of discerning which ways of doing theology are excluded by norms of AT has been taken up less polemically via, e.g., Rea's engagement with Merold Westphal in "Introduction," Analytic Theology, 9-15 or Marilyn McCord Adams's “What's Wrong with the Ontological Error?” Journal of Analytic Theology 2 (2014): 1-12. 
Forthcoming in Marginalized Identities, Peripheral Theologies: Expanding Conversations in Analytic Theology, edited by Michelle Panchuk and Michael Rea (Oxford University Press). 3-6-2019 Draft, please do not cite without prior permission.

a theologian does not need to adhere to any substantive theological or philosophical views in order to count as an analytic theologian. She only needs to explicate whatever substantive views she does hold using the tools and methods of analytic philosophy. ${ }^{5}$

However, when one looks at the existing literature in AT to see how the formal model is actually being enacted, the empirical reality one discovers is

a substantive theological program: theology that draws on the tools and methods of analytic philosophy to advance a specific theological agenda, one that is, broadly speaking, associated with traditional Christian orthodoxy. ${ }^{6}$

By "traditional Christian orthodoxy," Wood seems to have in mind something like "conciliar" or "creedal" Christianity. However, the theological association of AT with traditional orthodoxy in that sense may be construing AT too narrowly. It is more accurate, I think, to say that AT has been associated with traditional Christian orthodoxy in a broader sense that encompasses the literatures and debates of the mainstream Western European and American theological canon - one that does not exclude figures often credited (or debited) with breaking from the creedal and conciliar tradition, such as Schleiermacher, Bultmann or Tillich.

LT, on the other hand is characterized by a critical posture toward the established Western theological canon, not only in its maintenance of a generally theologically conservative Christianity but also in its more traditionally liberal revisions, insofar as both that conservative tradition and its liberal revisions can be thought to mediate various forms of social and political injustice and oppression. ${ }^{7}$ But one finds it difficult to find any monographs or articles intuitively recognizable as instances of AT that have as their primary purpose to substantially engage the positions, literatures, or debates that define contemporary LT. At best, there have been a few analytic theologians (Sarah Coakley chief among them) who have broached the concerns of feminist theology from within that traditional theological canon. ${ }^{8}$ Nevertheless, there remains no discernible strand of AT

5 Wood, "Trajectories," 255.

${ }^{6}$ Ibid.

${ }^{7}$ Devin Singh follows Jon Sobrino in distinguishing two distinct philosophical trajectories in the Western tradition: the more dominant one that runs from Kant to various post-Kantian projects, and the less dominant one that runs from Marx to various radical social and political philosophies. Whereas Christian theology and philosophy of religion has tracked with the various developments of the post-Kantian legacy, liberation theology (particularly in its Latin American instantiation) has found a greater resource in Marxist thought. See Singh, "Liberation Theology," in The Epistemology of Theology, edited by William Abraham and Fred Aquino (New York: Oxford University Press), 552.

${ }^{8}$ See Sarah Coakley, Powers and Submissions: Spirituality, Philosophy and Gender (Oxford: Wiley-Blackwell, 2002); God, Sexuality and the Self: An Essay “On the Trinity' (New York: Cambridge University Press, 2013). On my reading, Coakley's significance as a feminist theologian consists precisely in her creative attempts to construct a Christian feminism normed by orthodox Christian theological traditions (especially those retrospectively identified as "Christian mysticism"). As a traditionalist of sorts, her feminist credentials are often subject to scrutiny by Christian feminist theologians who take up a critical 
Forthcoming in Marginalized Identities, Peripheral Theologies: Expanding Conversations in Analytic Theology, edited by Michelle Panchuk and Michael Rea (Oxford University Press). 3-6-2019 Draft, please do not cite without prior permission.

that contributes centrally to the current state of black or womanist theologies, more critical and revisionary feminist theologies, queer theologies, or any other radical social and political theologies.

The lacuna is striking, because the development of AT from its forbearers in analytic philosophy of religion has managed to generate fruitful engagement with a host of other movements in academic theology. The growth of AT has, for instance, generated many works of confessional or ecclesial theology including evangelical, ${ }^{9}$ Reformed, ${ }^{10}$ liberal Protestant, ${ }^{11}$ and Roman Catholic theologies. ${ }^{12}$ Analytic theologians have emerged from amongst various theological orientations - there are prominent analytic Thomists, ${ }^{13}$ analytic Calvinists, ${ }^{14}$ analytic Barthians, ${ }^{15}$ Schleimeracherians, ${ }^{16}$ and more. Analytic theologians have accordingly waded into various meta-theological debates over the proper aims, methods and sources in theology as these are construed in conservative, ${ }^{17}$ liberal, ${ }^{18}$ and post-liberal theology. ${ }^{19}$ Why, then, given this impressive and ambitious intellectual market-share in contemporary academic theology, have analytic theologians by and large failed to so much as engage or assess - much less generate - any substantial LT? Why should one-thousand other analytic theological flowers bloom while this one has not even begun to bud?

One suggestion might be that AT and LT are simply incompatible with one another. Perhaps what Wood calls the "formal model" of AT logically excludes or makes very unlikely something essential to the project of LT. To assess whether there is any such incompatibility, we need working definitions of AT and LT. Michael Rea's account of AT has been perhaps the most widely endorsed. Rea emphasizes that AT is not adequately characterized by any shared substantive philosophical theses in analytic philosophy that all analytic theologians endorse as such, because there are no such theses.

stance toward those traditions as more corrupted by patriarchy than Coakley allows. See, e.g., Anna Mercedes's Power For: Feminism and Christ's Self-Giving (New York: T\&T Clark, 2011), or Linn Tonstad, God and Difference: The Trinity, Sexuality and the Transformation of Finitude (New York: Routledge Press, 2017).

${ }^{9}$ See, e.g., Thomas McCall's An Invitation to Analytic Theology (Downers Grove, IL: IVP Academic, 2015).

${ }^{10}$ See, e.g., Oliver D. Crisp, Deviant Calvinism: Broadening Reformed Theology (Minneapolis, MN: Fortress Press, 2014).

${ }^{11}$ See e.g., Andrew Dole, Schleiermacher on Religion and the Natural Order (New York: Oxford

University Press, 2010).

${ }^{12}$ See e.g., Timothy Pawl, In Defense of Conciliar Christology: A Philosophical Essay (New

York: Oxford University Press, 2016.

${ }^{13}$ For example, John Haldane, Bruce Marshall, Eleonore Stump

${ }^{14}$ For example, Oliver Crisp, Ray Yeo.

${ }^{15}$ For example, Kevin Diller, Alan Torrance.

${ }^{16}$ For example, Robert Adams, Andrew Dole.

17 See, e.g., McCall, An Invitation to Analytic Theology.

${ }^{18}$ See, e.g., William Wood, "Analytic Theology as Liberal Theology," paper presented at Fuller Theological Seminary's Colloquium in Analytic Theology, Pasadena, CA: April 12, 2017.

${ }^{19}$ See, e.g., Sameer Yadav, "Christian Doctrine as Ontological Commitment to a Narrative," in The Task of Dogmatics: Explorations in Theological Method (Grand Rapids: Zondervan, 2017), 70-86. 
Forthcoming in Marginalized Identities, Peripheral Theologies: Expanding Conversations in Analytic Theology, edited by Michelle Panchuk and Michael Rea (Oxford University Press). 3-6-2019 Draft, please do not cite without prior permission.

Rather, AT is just any sort of theology that adopts the ambitions and the style broadly exhibited in contemporary analytic philosophy. Those ambitions are

(i) to identify the scope and limits of our powers to obtain knowledge of the world, and (ii) to provide such true explanatory theories as we can in areas of inquiry (metaphysics, morals and the like) that fall outside the scope of the natural sciences. ${ }^{20}$

In addition to these ambitions, Rea characterizes AT as rhetorically conforming to five stylistic prescriptions widely exhibited in contemporary analytic philosophy:

P1. Write as if philosophical positions and conclusions can be adequately formulated in sentences that can be formalized and logically manipulated. P2. Prioritize precision, clarity, and logical coherence.

P3. Avoid substantive (non-decorative) use of metaphor and other tropes whose semantic content outstrips their propositional content.

P4. Work as much as possible with well-understood primitive concepts, and concepts that can be analyzed in terms of those.

P5. Treat conceptual analysis (insofar as it is possible) as a source of evidence. $^{21}$

The virtues of Rea's way of identifying AT include its minimalism, its success in capturing our intuitions about what might rightly be judged to be instances of AT, and despite its minimalism its nonetheless managing to say something substantive about what makes AT distinct from non-analytic ways of doing theology. It is also important to note that Rea's analysis aims to be descriptive, not normative - it does not attempt to prescribe what AT ought to be, but only to plausibly describe what it is. Offering a similarly virtuous descriptive definition of LT that can capture whatever it is that unites all liberation theologians across all of the width and depth of their mutual disagreements would be a difficult undertaking. Just as there are no substantive philosophical theses shared by all analytic theologians, there are likewise no substantive theses regarding the proper subjects, grounds, means or methods of LT among liberation theologians.

Nevertheless, LT can similarly be marked out in terms of a shared ambition in theology, as well as two shared meta-theological commitments about the normative role played by that ambition in theological theorizing.

The defining feature of LT is the commitment to a liberative ambition in theology, which can be summarized as the ambition to do theology in service of the cognitive and practical goals of securing freedom for groups who suffer social or political oppression. A key feature of LT, however, is that this ambition is intended to serve not merely as a psychological motivator for liberation theologians or as a mere moral scruple, but as a meta-theological norm for theology as such. On some explications of the liberative norm for theology, a liberative ambition must be satisfied in order for any putative instance of

\footnotetext{
${ }^{20}$ Rea, "Introduction," in Analytic Theology, 4.

${ }^{21}$ Ibid., 5-6.
} 
Forthcoming in Marginalized Identities, Peripheral Theologies: Expanding Conversations in Analytic Theology, edited by Michelle Panchuk and Michael Rea (Oxford University Press). 3-6-2019 Draft, please do not cite without prior permission.

theology to genuinely count as theology at all. Thus, for example, we find James Cone (a founding figure of black liberation theology) claiming that "there can be no Christian theology that is not identified unreservedly with those who are humiliated and abused...Christian theology is never just a rational study of the being of God. Rather it is a study of God's liberating activity in the world, God's activity in [sic] behalf of the oppressed." 22

Cone appears to take the liberative ambition of LT to be a defining norm for Christian theology in the strong sense of imposing a condition that must be satisfied for the term "Christian theology" to be properly reference-fixing. Any putative instance of Christian theology that fails to live up to a liberative ambition is thus not an instance of Christian theology at all, but merely a Christian theology manqué. This meta-theological thesis about a liberative ambition in theology makes "Christian theology" a success term, such that the designative meaning of the term includes only that which satisfies that ambition. But not all liberation theologians make a liberative ambition normative for the meaning of "theology" per se. Some take that ambition to instead be a merely evaluative norm that determines whether any instance of theology counts as an instance of good theology, theology done well, properly, or as it ought to be done. On this weaker reading, there can be Christian theology that is "just a rational study of the being of God," and which is not essentially concerned with "God's liberating activity in the world," but Christian theology of that sort, in virtue of failing to satisfy a liberative ambition, is bad theology, theology poorly executed. ${ }^{23}$

As a matter of descriptive definition, I leave open the question of whether we ought to accept the stronger or the weaker reading of the meta-theological role that a liberative norm plays for LT - this seems to be an in-house debate among liberation theologians. There is much greater agreement, however, about the domains to which a liberative norm must be applied in order to satisfy a liberative ambition in theology. Namely, for any instance of theology to count as an instance of LT, it must serve the interest of securing freedom for a socially or politically oppressed group in two ways: (a) substantively and (b) methodologically. Theology exhibits a substantive interest in liberation only when its subject-matter is normatively determined by a liberative ambition, while it exhibits a methodological interest in liberation only when its mode of inquiry is normatively determined by a liberative ambition. Various kinds of LT are individuated by the forms of political and social oppression that substantively and methodologically motivate their theological theorizing.

In his Invitation to Analytic Theology, Thomas McCall claims that "there is nothing about analytic theology...that precludes the use of analytic tools by, say, feminist, womanist, or liberationist theologies." 24 Given that we take him to be referring

22 James Hal Cone, A Black Theology of Liberation (Maryknoll, NY: Orbis Books, 1986), 1, 3.

${ }^{23}$ See, for example, Margaret Kamitsuka's allowance for an internal dispute among feminist liberation theologians regarding what I'm calling strong and weak readings of the liberative norm in Feminist Theology and the Challenge of Difference (New York: Oxford University Press, 2007), 117ff.

${ }^{24} \mathrm{McC}$ all, Invitation, 29. 
Forthcoming in Marginalized Identities, Peripheral Theologies: Expanding Conversations in Analytic Theology, edited by Michelle Panchuk and Michael Rea (Oxford University Press). 3-6-2019 Draft, please do not cite without prior permission.

to what Wood calls the "formal model" of AT, and given the minimalistic formal definitions of AT and LT above, it should be clear enough that McCall is correct. There is nothing about the liberative ambition of LT or its proposed normative role for theological content and method that contradicts Rea's ambitions (i) or (ii), or any of his stylistic prescriptions P1-P5. It remains possible, of course, that there are liberation theologians who construe the kind of freedom from oppression constitutive of their theological theorizing in some way that runs contrary to the analytic ambitions or style constitutive of AT. For example, perhaps there are liberation theologians who embrace LT but who also think that trying to determine the scope and limits of our powers to obtain knowledge of the world is inconsistent with the explication of liberation for the oppressed. In that case such a construal of LT would be incompatible with AT in virtue of excluding one of the ambitions it adopts from analytic philosophy, i.e., the first one. Or perhaps there are liberation theologians who embrace LT but who take metaphorical meanings that outstrip their propositional content to be indispensable to the way that theology must methodologically convey freedom from oppression. Such a construal would be incompatible with AT in virtue of being inconsistent with one of the stylistic prescriptions it adopts from analytic philosophy, i.e., P3. Something similar might be said for a range of possible construals we might give to AT that would contradict LT as defined above. ${ }^{25}$

But potential inconsistencies of that kind do not show that LT per se is necessarily incompatible with AT per se, only that on some narrow range of construals, LT is incompatible with AT. There is thus no apparent logical incompatibility preventing analytic theologians from engaging in LT. Why, then, are there so few, if any, proponents of AT who also embrace LT? I doubt that proponents of AT are unaware of LT as a live option in academic theology. ${ }^{26}$ Rather, I suspect that proponents of AT fail to engage with or in LT principally because they misconstrue LT as engaged in an enterprise aimed at the moral or ethical consequences of Christian theology rather than as theology per se, or because they recognize LT's claim that a liberative ambition is an obligatory norm for (good) Christian theology per se, but regard that claim as obviously false. One might see how we could properly motivate a substantive and methodological commitment to a liberative ambition in theology as reasonable or permissible, but it seems prima facie implausible to suppose that Christian theologians in general, or analytic theologians as such are under any sort of obligation to adopt that ambition as constitutive of (good) Christian theology. There are, after all, plenty of truths about Christian theism other than its liberative dimension for which true explanatory theories appear to be perfectly well-motivated. Granting even the weaker version of LT, there is no apparent reason to suppose, for example, that whether or not God is a metaphysical simple makes much (if any) difference for human liberation, but it seems absurd to

${ }^{25}$ In private correspondence, Rea suggests a possible contradiction between a construal of AT as prizing "objectivity" and the anti-liberative dimensions of that notion as suggested in Sally Haslanger, "On Being Objective and Being Objectified, in Resisting Reality (New York: Oxford University Press, 2012), $35-82$.

${ }^{26}$ Still, this tends to be mere awareness. One observes a general ignorance among analytic theologians about the landscape and content of LT as a research agenda, and likewise, a general ignorance amongst proponents of LT about AT as a research agenda. 
Forthcoming in Marginalized Identities, Peripheral Theologies: Expanding Conversations in Analytic Theology, edited by Michelle Panchuk and Michael Rea (Oxford University Press). 3-6-2019 Draft, please do not cite without prior permission.

suppose that a true explanatory theory of divine simplicity would thus be an instance of bad theology. Moreover, any attempt to make a doctrine of divine simplicity satisfy a liberative criterion would seem at best a strange (at worse, a tortured) use of that doctrine, and this makes it seem bizarre to require that it satisfy that criterion in order to be considered (good) Christian theology.

If this diagnosis is correct - that AT (not formally, but as an active research program) has sidestepped LT either out of misunderstanding or out of a lack of confronting any plausible argument for it - then the goal of including LT within the ambit of AT would be well-served by offering a construal of LT that satisfies the following three desiderata. First, such a construal would have to make clear what it is that makes LT a meta-theological proposal about the proper content and method of Christian theology rather than merely an instance of normative ethics. Second, such a construal would have to challenge the underlying intuition about LT's obvious falsity that enables theologians to dismiss or neglect it as a serious meta-theological proposal. While such a desideratum doesn't demand a full-blown defense of LT it does seem to demand a plausible story about what makes a liberative ambition a necessary criterion for (good) Christian theology, and why instances of theological theorizing that do not satisfy that criterion merit the negative evaluation that the proponent of LT assigns to them. Finally, since such a construal is aimed at developing LT as a research program of AT, we should be able to see how it satisfies both the analytic ambitions of AT as well as broadly exemplifying its stylistic prescriptions P1-P5.

The remainder of the paper aims to offer a construal of LT that satisfies all three desiderata. My claim is essentially that any ambition of providing true explanatory theories in Christian theology (Rea's analytic ambition ii) must be guided by values beyond the narrowly epistemic that determine the relative cognitive and practical significance of theological explananda and explanata - and this is so however one prefers to theorize the nature of epistemic value per se. In the second section below, I offer a philosophical framework for thinking about how various sorts of values might impinge one another in normatively guiding our practices. In a third section, I make the case that the particular configuration of epistemic and non-epistemic values for the practice Christian theology that obligates Christian theologians, including Christian analytic theologians, to be guided in their theory-construction by the moral and prudential value of the liberation for the socially and politically oppressed. I go on in a fourth section to elaborate some of the constraints on content and method in theology that we might expect to find if we construe Christian theology as in part constituted by its liberative value as LT claims. As the specification of a meta-epistemological normative constraint on the scope and limits of our power to obtain theological knowledge, LT therefore also satisfies Rea's ambition i. Having thus shown how the liberation theologian can make a case for LT that appeals to the ambitions constitutive of AT and in a style consistent with AT, I conclude with some brief suggestions about what an analytic theology of liberation as a research program of AT might involve. 
Forthcoming in Marginalized Identities, Peripheral Theologies: Expanding Conversations in Analytic Theology, edited by Michelle Panchuk and Michael Rea (Oxford University Press). 3-6-2019 Draft, please do not cite without prior permission.

\section{Values and Reasons for Acting: Pro Tanto vs. All things Considered}

On Rea's analysis, AT is theological inquiry guided by the analytic ambition of seeking to "provide such true explanatory theories as we can." 27 Since AT is just "the activity of approaching theological topics with the ambitions of an analytic philosopher," 28 the analytic theologian is therefore someone who approaches the subject matter of Christian theology not only with the resources of analytic philosophy but also its aim of providing true explanatory theories regarding that subject matter. The proponent of LT can accept this minimal conception of the aim of theological theorizing, but liberation theologians would regard it as an insufficient specification of that goal. On the weaker reading of LT, a necessary condition of any theological theory's being a good theological theory is that it aims not merely at truth, but also at justice for the socially and politically oppressed. How might one go about motivating and defending that claim?

I think a case for LT can be made on the basis of a commonly held view in contemporary analytic epistemology that, as in ethics or aesthetics so too in epistemology, the right is grounded in the good. ${ }^{29}$ Our epistemic permissions and obligations, whatever they are, are grounded in epistemic value in a parallel sort of way that aesthetic, moral or prudential duties are respectively grounded in aesthetic, moral or prudential value. If it is true that we have a moral obligation not to commit genocide, then this is because genocide is morally bad, and mutatis mutandis for prohibitions arising from aesthetic and prudential badness. Similarly, if we are morally permitted (but not morally obligated) to pursue a graduate degree, then this is because getting a graduate degree is not morally bad, and mutatis mutandis for permissions arising from aesthetic and prudential not-badness. Likewise, if we have an epistemic obligation to avoid falsehood and pursue truth in our beliefs, this is because false beliefs are epistemically bad, and if we are epistemically permitted, but not required, to ignore certain kinds of evidence, this is because ignoring it is not epistemically bad.

The various kinds of norms governing our beliefs and practices are not merely grounded in absolute values of good and bad, but also in comparative values of better and worse. For example, if from a moral standpoint we have an obligation to prefer the cultivation of virtue to mere continence, then this is because, considered from that standpoint, virtue is better than mere continence. If from an aesthetic standpoint we have an obligation to prefer a Picasso to a Kincaid, then this is because, considered from that standpoint, the Picasso is aesthetically better than the Kincaid. On the other hand, if we are aesthetically permitted to prefer whichever we like or neither, then it is because one is

${ }^{27}$ Rea, "Introduction," 4.

${ }^{28}$ Ibid., 7.

${ }^{29}$ Of course, the common view has been challenged. See, e.g., Charles Cote-Bouchard, "Is Epistemic Normativity Value-Based?” Dialogue 56/3 (2017): 407-430. My argument in favor of LT can therefore be interpreted as establishing only a conditional claim, "if the common view is correct, then Christian theologians ought to be committed to LT." Nevertheless, in order to avoid the cumbersome intrusion of constant conditional qualification, I simply proceed henceforth as if the more commonly held view were correct. 
Forthcoming in Marginalized Identities, Peripheral Theologies: Expanding Conversations in Analytic Theology, edited by Michelle Panchuk and Michael Rea (Oxford University Press). 3-6-2019 Draft, please do not cite without prior permission.

not objectively better than the other from the aesthetic point of view. Likewise, if from an epistemic standpoint we have an obligation to prefer the acquisition of true beliefs by way of knowledge rather than, say, luck, this is because, considered from that standpoint, knowledge is epistemically better than merely true belief. If it is epistemically permissible to believe either truths of trivial existential import or truths of great existential import, this is due to the fact that neither class of truths is better than the other, considered from an epistemic point of view.

Finally, in our failure of conformity to the norms grounded in the relevant values, we are subject to blame from these corresponding evaluative standpoints. Our accountability to the norms rationally afforded us by these various kinds of value consists minimally in our responsibility to avoid blameworthiness in what we think, say and do. Our failing to respond to the prohibition on genocide rationally afforded by its badness makes us morally blameworthy. Where the pursuit of virtue is morally preferable to the pursuit of mere continence, we can become morally culpable for eschewing virtue in favor of mere continence. Likewise, for most ordinary adults, believing that the moon is made of cheese is blameworthy from an epistemic point of view insofar as it involves some culpable failure to respond to the epistemic badness of that belief (i.e., its being false or epistemically unjustified); if not, believing it is epistemically blameless. ${ }^{30}$

We can thus recognize a structural parallel between various kinds of goodness, the corresponding kinds of norms fixed by them, and our rational accountability to those norms. But the way that these distinct kinds of value and their corresponding norms impinge upon us in our practices is not neatly distributed. Virtually nothing we think, say or do matters in only one kind of way (e.g., morally but not epistemically, prudentially, aesthetically, or aesthetically but not morally, prudentially, epistemically, etc.). Accordingly, virtually nothing we think, say or do is responsive to only one class of normative reasons or subject to appraisal from only one evaluative point of view. Rather, most of the practices we choose to undertake exhibit a complex profile of distinct respects in which such practices are good and bad, and a corresponding complex of comparative considerations about which among these goods are most worth having and thus which normative considerations fix our permissions and obligations.

Because of the multi-dimensional value profile of any given course of action we might undertake, the various normative considerations that guide our acting (or refraining from acting) can be related to one another in different sorts of ways. What we have reasons to do given one dimension of value, pro tanto (i.e., as far as that value is concerned) might agree with what we have reasons to do given another distinct dimension of value, also considered pro tanto. For example, under certain circumstances,

30 There are many complications here about the nature of culpability connected to the notion of rational affordance. Should we think of such affordances in internalist or externalist terms? Should we think of them as defeasible or not? Is our doxastic blameworthiness dependent on that which is within our voluntary control? Do different classes of norms merit different answers to these questions and thus different analyses of culpability? Etc. I don't intend to prejudge on any of these questions. It is enough for my purposes that each distinct sort of value imposes a corresponding sort of norm and that each distinct sort of norm imposes a corresponding basis of rational evaluation for our beliefs and practices. 
Forthcoming in Marginalized Identities, Peripheral Theologies: Expanding Conversations in Analytic Theology, edited by Michelle Panchuk and Michael Rea (Oxford University Press). 3-6-2019 Draft, please do not cite without prior permission.

it might be that my deciding to go to a baseball game is not a morally, aesthetically, epistemically or prudentially bad thing to do, while deciding not to go would also not be bad in any of those respects. Thus, all things considered, I can rightly regard my going or not going to the baseball game as permissible from every evaluative point of view. In cases like this, where one evaluative point of view would guide us to act in the same way as any another, the permissibility of acting considered from one evaluative point of view in isolation from the other dimensions of value (i.e., considered pro tanto) would not be affected at all by any further and final consideration of any other dimensions of value that might be relevant to the act.

However, in many cases a consideration of what we are permitted or obligated to do from only one evaluative standpoint, pro tanto, is insufficient for discerning what our duties are. ${ }^{31}$ For example, suppose there is someone who is being severely and unjustly harmed by my boss and that I am the only person in a position to expose the injustice and prevent further harm. But I am also the primary breadwinner for my family with no prospects for alternative work and exposing my boss would almost certainly damage my career, perhaps even getting me fired. Considered from a purely prudential point of view, I ought to refrain from exposing my boss due to the prudential badness of putting my livelihood in jeopardy, while considered from a purely moral point of view, I ought not refrain from exposing my boss due to the moral badness of becoming complicit in an injustice. My exposing my boss could be regarded as prudentially blameworthy but morally blameless while the reverse is true for my refraining from doing so.

Given the conflict in normative considerations generated by the value-profile of my action, knowing what I am permitted or obligated to can in this way depend on knowing which value ought to trump the other in guiding my actions, and this is a matter of knowing which sort of outcome ultimately matters more. In order to resolve the dilemma about exposing my boss I must determine which is the more important aim to achieve - the prudential aim of preserving my job or the moral aim of preventing the injustice. To take a less controversial example: suppose I have an idiosyncratic and overwhelming hatred for wet shoes but also recognize a moral obligation to help people in need, and I subsequently encounter a child who is drowning but whom I cannot help without getting my shoes wet. The prudential badness of wet shoes might give me a pro tanto prudential reason to suppose that I ought not help the child, but it does not give me an all things considered reason to refrain from helping. Rather, taking the relative badness of wet shoes as compared with dead children into account, I should obviously take the moral badness of the latter to outweigh or override the prudential badness of the former. I should aim at moral good of saving the child, my shoes be damned, because the moral value of helping is, all things considered, better than the prudential value of dry shoes. $^{32}$

${ }^{31}$ See, e.g., Danny Frederick, "Pro-tanto Obligations and Ceteris-parabus Rules," Journal of Moral Philosophy 12/3 (2015): 255-266.

32 This does not necessarily mean that there is any overarching dimension of value transcending moral and prudential value that affords a "commensurating" standpoint from which to compare them, for it could also be that there are principled ways in which the norms fixed by moral value include prudential considerations, and vice-versa. Compare, e.g., Ruth Chang, "All things considered," Philosophical 
Forthcoming in Marginalized Identities, Peripheral Theologies: Expanding Conversations in Analytic Theology, edited by Michelle Panchuk and Michael Rea (Oxford University Press). 3-6-2019 Draft, please do not cite without prior permission.

More generally, then, when acting or refraining from acting in some way that is permissible or favored pro tanto is nevertheless impermissible all things considered, it is because the good (or at least not bad) end at which it aims according to one evaluative standpoint would nevertheless not be good enough considered from another evaluative standpoint so as to override or outweigh the reasons one might have had to act or refrain from acting in accordance with one's merely pro tanto reasons permitting or favoring it. This eminently plausible principle accords with our intuitions about the badness, wrongness and blameworthiness of acting or refraining from acting in ways that prefer what is less valuable or important over that which, by comparison, we have sufficient reason to value more, even if the relevant overriding or outweighing value is of a different sort. Nor does the principle require us to hold that genuine goods can conflict with one another. What conflicts is rather the relative preferability of acting on some (types of) goods as compared with others. It might also be that for any possible action situation, some sorts of goods (e.g., moral) always override others (e.g., prudential) in relative preferability.

\section{Liberation and the Value of True Explanatory Theories in Theology}

The central claim of LT is just that theological inquiry, while accountable to epistemic goodness, nevertheless exhibits normative encroachment by other kinds of value. The fact that we are engaged in practices of belief formation aimed at epistemic goods of truth, knowledge or understanding does not ensure that those practices are entirely unconstrained by moral, aesthetic and prudential considerations as relevant factors in our search for truth, knowledge or understanding. Recognizing the relevant kind of encroachment does not require liberation theologians to hold to any substantive epistemological theses about, e.g., pragmatic encroachment on knowledge of the sort endorsed by Stanley, Hawthorne, Fantl \& McGrath, etc. The claim is not that non-alethic considerations might determine whether or not someone may in fact be rightly said to possess theological knowledge. The claim instead is that what we ought to seek to know and how we ought to seek to know it in theology must be guided by moral and prudential norms over and above epistemic norms, whether or not epistemic norms properly understood include some non-alethic considerations. Considered pro tanto, epistemic values are too permissive to determine what we ought to theorize about and how. Construing our goal of theory-construction solely in terms of amassing truths or acquiring knowledge confronts a practical problem that we could term "the problem of plentitude": there are simply too many truths and thus too much to know about any given subject matter we might be inclined to theorize about.

Consequently, in all our knowledge-seeking activities, including that of theory-

Perspectives 18/2 (2004): 1-22, and Mathias Slåttholm Sagdahl, "The Argument from NominalNotable Comparisons, 'Ought All Things Considered,' and Normative Pluralism," Journal of Ethics 18 (2014): 405-425. 
Forthcoming in Marginalized Identities, Peripheral Theologies: Expanding Conversations in Analytic Theology, edited by Michelle Panchuk and Michael Rea (Oxford University Press). 3-6-2019 Draft, please do not cite without prior permission.

construction, we must draw on non-epistemic values to determine what we ought and ought not theorize about as all things considered normative constraints on the pro tanto epistemic permissiveness on of search for truth. For example, consider the project of bringing all the speculative and revealed resources of the Christian intellectual tradition to bear on the question of which type of flooring God most prefers in a church. Or consider the project of partially explaining the scope and content of divine omniscience by successively performing plus-one operations on a random number. Suppose that for each of these projects of knowledge-seeking there is some fact of the matter about what is to be explained and that we have sufficient reason to suppose that the means of theorizing at our disposal stand a good chance of making the facts we are targeting accessible to us. If epistemic value were the only normative consideration for theological theory-choice, then both of these projects would be eminently worth pursuing to achieve that goal.

Theological knowledge, like knowledge generally, is not terribly valuable to have in and of itself. ${ }^{33}$ On whatever theory of its intrinsic value you adopt, what makes it worth having is its instrumental value for acquiring non-epistemic goods that we care about in an overall theory of human flourishing - a theory that coordinates and integrates the epistemic, aesthetic, moral and prudential goods constitutive of our cognitive and practical lives. As Ernest Sosa has recently argued, it is not so much the intrinsic value of knowledge that makes it worth having, but its instrumentality for a flourishing life. It is only "knowledge of certain matters [that] adds so importantly to the flourishing of one's life individually, and of life in community." 34 Sally Haslanger had developed this thought of Sosa's at least a decade earlier, but highlights both the regulative role that the notion of human flourishing plays in the practice of theorizing and the potentially controversial nature of that notion:

[G]ood theories are systematic bodies of knowledge that select from the mass of truths those that address our broader cognitive and practical demands. In many contexts the questions and purposes that frame the project are understood and progress does not require one to investigate them. But in other contexts, e.g., especially when debate has seemed to break down and parties are talking at cross-purposes, an adequate evaluation of an existing theory or success in developing a new one is only possible when it is made clear what the broader goals are. ${ }^{35}$

Like Sosa, Haslanger appeals to a quasi-Aristotelian notion of eudaimonia or some conception of the natural, social and political conditions of individual and

${ }^{33}$ Notice that this is consistent with holding that all knowledge per se is intrinsically valuable. It is just that, all things considered, we don't have compelling or overriding reasons to seek knowledge for the sake of its merely intrinsic value, irrespective of its practical value. $189-190$

${ }^{34}$ Ernest Sosa, "Value Matters in Epistemology," The Journal of Philosophy 107/4 (April, 2010):

${ }^{35}$ Sally Haslanger, "Gender and Race: (What) Are They? (What) Do We Want Them to Be?" Noûs 34/1 (2000), 31-55: 35. 
Forthcoming in Marginalized Identities, Peripheral Theologies: Expanding Conversations in Analytic Theology, edited by Michelle Panchuk and Michael Rea (Oxford University Press). 3-6-2019 Draft, please do not cite without prior permission.

communal human flourishing. ${ }^{36}$ Like Sosa, Haslanger recognizes that it is some such shared background story about the social and political conditions of human flourishing individually and in community that gives us a shared background for determining the non-epistemic cognitive and practical goods that encroach on our search for knowledge via our doxastic practices of theory-construction. It is this shared background that explains our shared judgments about what would make some true explanatory theories in theology (like divine flooring theory or divine number-knowledge theory) not worth having as compared with, say a theory about why God allows evil to exist in the world.

But unlike Sosa, Haslanger also recognizes that what counts as the cognitive and practical goods that guide what we should judge to be comparatively better and worse matters for theologically theorizing, what we ought therefore to prefer to theologically theorize about, and what we are thus blameworthy for failing to prefer theorizing about are often a matters of dispute. LT is predicated on the fact that we need to know, broadly, what non-epistemically matters and also what matters more and less in order to know how to construct and evaluate all things considered good theories in theology. But it also contends for a particular substantive claim about what in some sense matters most - social and political oppression matters in such a way as to outweigh or override other competing non-epistemic goods that might guide our search for truth, knowledge or understanding in theology.

LT's criticism of "traditional" theology as "bad" theology is not only that it neglects the importance of freedom from oppression as an essential moral and prudential constraint on giving true explanatory theories in theology. Rather, the worry is that much traditional theology is undergirded by an assumed or implicit eudaimonistic background that it fails to acknowledge and critically examine. Some such background picture of human flourishing is bound to be highly contestable while also determining what sorts of theological theory-construction are deemed most worth pursuing. By failing to identify or critically interrogate the values that guide theory-choice, it is often unclear just what the cognitive or practical goals are that make a good deal of traditional AT worth doing, even if it were to yield true explanatory theories. This is one way of understanding a trope commonly expressed by liberation theologians in criticism of a kind of "scholasticism" in theology. The "scholastic disposition" as described by sociologist Pierre Bourdieu is just that sharply divorcing the task of theorizing from our moral and prudential interests in what we are theorizing about. ${ }^{37}$ While questionably connected to the medieval movement of theology from the monastery into the school, theologians such as J. Kameron Carter and Willie Jennings who appeal to Bourdieu to criticize a "scholastic disposition" in theology are not so much criticizing any particular historical conception of theology as a theoretical rather than practical science. Rather, they are criticizing a tendency to neglect the activity of theologizing itself as one necessarily

${ }^{36}$ Haslanger, "What Knowledge is and What it Ought to Be," Philosophical Perspectives 19 (1999): 471.

${ }^{37}$ See Willie James Jennings, The Christian Imagination (New Haven: Yale University Press, 2011), 7; J. Kameron Carter, Race: A Theological Account (New York: Oxford University Press, 2008):

373. Pierre Bourdieu, "The Scholastic Point of View," Cultural Anthropology 5/4 (1990): 380-91. 
Forthcoming in Marginalized Identities, Peripheral Theologies: Expanding Conversations in Analytic Theology, edited by Michelle Panchuk and Michael Rea (Oxford University Press). 3-6-2019 Draft, please do not cite without prior permission.

shaped by the practical concerns of our eudaimonistic interests, and encouraging us instead to theorize what it is to do theology "on the basis of .... a non-practical point of view founded upon the neutralization of practical interests and practical stakes." ${ }^{38}$ In contrast, LT consists in recognizing that, as Michael Eric Dyson puts it, "learning takes place in a world of trouble," imposing on our knowledge-seeking an explicit accountability to non-epistemic goods and non-epistemic virtues. ${ }^{39}$ Since our knowledge-seeking takes place against the background of the cognitive and practical interests and stakes associated with our flourishing as individuals and in communityinterests and stakes thoroughly shaped by unjust and oppressive social arrangements - the scholastic disposition to prefer the pro tanto epistemic permissiveness of theological knowledge-seeking to transcend these actual non-epistemic demands on our theorizing is unjustified, all things considered.

For the practice of, say, theoretical physics, or pure mathematics, the nonepistemic interests and stakes in our knowledge-seeking seem to be clearly contextual rather than constitutive constraints on our theorizing-immorality among mathematicians might corrupt the practice of mathematical theorizing, but it does not necessarily corrupt the content of mathematical theory. ${ }^{40}$ Similarly, liberation theologians have likewise thought it important to identify practical interests as contextually guiding theology. Thus, whereas analytic theologians in thrall to the scholastic disposition have attempted to offer true explanatory theories about the divine nature on the basis of, e.g., perfect being theology, liberation theologians have responded by critiquing the practical interests served by those theories, including the ways in which such theories might historically and presently function as technologies of oppression for, e.g., women, sexual minorities,

${ }^{38}$ Bourdieu, 383. I suspect that the scholastic fallacy as a problem of performative contradiction is a good way of understanding Haslanger's critique of, e.g., sexist knowledge attributions as a performative problem of the "utterance conditions" rather than truth-conditions of our speech, wherein we engage in performative utterances that contradict our assumed background commitments to, e.g., equality, autonomy, etc. See Haslanger, "What Knowledge Is and Ought to Be," 463-465. Despite the intuitive appeal of seeing some kind of performative contradiction involved in analyzing beliefs constitutive of religious practice from a standpoint that ignores the practical constraints on truth-seeking, some further work would need to be done to clarify what the charge of performative incoherence amounts to. For some useful analyses on that, see José Antonio Errázuriz, "The Performative Contradiction as an Argumentative Device: An Analysis of its Reach and Scope," Logique et Analyse 225 (2014): 15-44; Jaakko Hintikka, “Cogito, Ergo Sum: Inference or Performance?" The Philsophical Review 71/1 (Jan. 1962): 3-32; Eric Dayton, "Pragmatic Contradiction," Ethics 87/3 (April 1977): 222-236.

${ }^{39}$ Quoted in Carter, 376.

${ }^{40}$ See Elizabeth Anderson, "Knowledge, Human Interests, and Objectivity in Feminist Epistemology": "Is physics a 'pure' science? In the twentieth century, a highly significant question for physics has been: under what conditions will a mass of fissionable material enter into an uncontrolled nuclear reaction? This question is significant only because states of have conceived a political interest in building nuclear weapons and have funded most research in physics with military ends in mind. Is even number theory a 'pure' science? A significant question in number theory includes: what algorithms can rapidly factor very large numbers? This question is significant only because states and businesses have political and commercial interest in constructing and decoding encrypted messages. There is no clear way to isolate a special subset of sciences or fields of inquiry in which no such interests play a role in defining significance, and hence in which no such interests play a role in theory choice" (43). 
Forthcoming in Marginalized Identities, Peripheral Theologies: Expanding Conversations in Analytic Theology, edited by Michelle Panchuk and Michael Rea (Oxford University Press). 3-6-2019 Draft, please do not cite without prior permission.

those with disabilities and people of color. ${ }^{41}$ Most often, the rejoinder to critiques like that is that even if, e.g., divine power has been associated with male power in a way that has proven disastrous for women, this is theologically irrelevant just insofar as it may nevertheless be true that a divine being is necessarily omnipotent. Liberationist criticisms, it is alleged, name a historically contingent fact about a classical conception of divine omnipotence, namely that such a conception happens to have been put to bad use - a fact that is independent of and hence irrelevant to the question of its truth.

Indeed, there are liberation theologians who take the moral or prudential badness of traditional perfect being theology to be evidence of its epistemic badness as well, and who therefore go looking for alternative theories of God. But even if the inference from moral and/or prudential badness to epistemic badness is itself epistemically bad, ${ }^{42}$ it does not follow that the moral and prudential badness is irrelevant. True, it is irrelevant for our all things considered view of the truth of, e.g., perfect being theology. Still, it might be highly relevant for revising our all things considered view of the importance of engaging in perfect being theology, or the moral and practical value of engaging in it in one way rather than another. If a theologian holds or assumes a picture of human flourishing that is significantly undermined by the relevant moral or prudential badness of a true explanatory theory in theology, then this might give that theologian a pro tanto reason for revising her interests in pursuit of that theory. If the relevant theory is some species of perfect being theology that has been weaponized against the flourishing of women, this might rationally require her to make more explicit the patriarchal interests and stakes in our pursuit of perfect being theology. The chequered history of perfect being theology as a means for comprehending or worshipping God in Western Christianity might even afford her a decisive reason to move away from traditional ways of theorizing divine perfection as something worth doing in theology, or at any rate something worth doing independently of or at the expense of the limited epistemic resources we might devote to theologically theorizing the liberation of women from the church's misuse of divine omnipotence.

All things considered, therefore, it is our eudaimonistic interests that govern our

${ }^{41}$ See, for example, William Jones, Is God a White Racist? (Boston: Beacon Press, 1998); Anna Mercedes, Power For: Feminism and Christ's Self-Giving (New York: Bloomsbury, 2011).

42 Though I also believe that the matter is not so simple as it is sometimes made to appear. The inference from moral or prudential badness to epistemic badness in theology often functions against the background of some assumptions about the semantic/pragmatic interface of theological language, and divine intentions in self-revelation. If the meaning and use of theological terms/sentences are inextricably linked (e.g., if their aptness for certain uses figures into the satisfaction conditions of those terms or truthconditions of those sentences), then maybe the inference from moral/prudential badness to epistemic badness goes through. Similarly, suppose divine self-revelation is given for the sake of the creation of a particular kind of community, but that there is no evidence that an understanding of God as construed in the classical tradition can properly motivate or generate the requisite sort of community, while there is a lot of evidence that such an understanding of God discourages the requisite kind of community. That would seem to count as evidence against a classical understanding of God. Perhaps the linguistic as well as the revelatory arguments that liberation theologians sometimes make and sometimes assume face insuperable difficulties. Still, those arguments and assumptions should be engaged rather than ignored or cavalierly dismissed. 
Forthcoming in Marginalized Identities, Peripheral Theologies: Expanding Conversations in Analytic Theology, edited by Michelle Panchuk and Michael Rea (Oxford University Press). 3-6-2019 Draft, please do not cite without prior permission.

practices of theological knowledge-seeking, and that those interests include not only whatever it is that epistemic value contributes to our flourishing individually and in community, but also whatever non-epistemic moral, prudential and aesthetic values contribute to our flourishing. Whatever sort of eudaimonism serves as a guiding norm in our search for true explanatory theories in theology, therefore, our practice of theorizing must attend to the ways that our (true) theological theories might or do in fact practically undermine our eudaimonistic interests. "Good" theology is not merely epistemically good theology but eudaimonistically good theology. Still, why think that social and political oppression takes any kind of privileged place as a criterion for meeting an all things considered eudaimonistic constraint on theological knowledge-seeking? There are plenty of possible ways of thinking about a theological picture of human flourishing individually and in community on which freedom from social and political oppression in this life is neither a necessary nor sufficient condition of that flourishing. Still, I think liberation theologians can plausibly hold that freedom from social and political oppression is not merely a contextual value of Christian theology but also a constitutive one, a defining feature of its subject matter.

\section{Liberation as Subject Matter and Method of Christian Theology}

Liberation theologians have by and large recognized the disagreement that arises regarding the significance of social and political oppression in this life that they require as a minimally adequate specification of the eudaimonism that normatively constrains theological knowledge-seeking. To do Christian theology, however, means that one's theory-choice and what one deems worthy of pursuing theologically must be consistent with (and, perhaps, justified with reference to) a minimally Christian conception of human flourishing, individually and in community. Relying on a Christian conception of eudaimonistic goodness in our theory of the eudaimonistic goodness of theological theorizing admits of a benign kind of epistemic circularity, ${ }^{43}$ in a similar sort of way that, e.g., Plantinga supposes that we must rely on a Christian conception of the epistemic goodness of Christian belief in our theory of the epistemic goodness of Christian belief. ${ }^{44}$

There is, it seems to me, a good case to be made that the amelioration of social and political oppression in the present life is a crucially important and thematically central feature of a Christian picture of human flourishing individually and in community. I won't offer any full-blown case for that here, but just mention a few significant reasons to think it plausible. A Christian story of God's creation and redemption of the world is essentially structured by a "problem/solution" paradigm in which the problem centers on the fall of humanity from a place of cooperative caretaking over the portion of creation to which human life is bound. The vocation of humanity that

${ }^{43}$ See William P. Alston, "Epistemic Circularity," Philosophy and Phenomenological Research 47 (1986). Reprinted in Epistemic Justification: Essays in the Theory of Knowledge (Ithaca: Cornell

University Press, 1989): 319-349; Michael Bergmann, "Epistemic Circularity: Malignant and Benign," Philosophy and Phenomenological Research 69 (2004): 709-727.

${ }^{44}$ See Alvin Plantinga, Warranted Christian Belief (New York: Oxford University Press, 2000). 
Forthcoming in Marginalized Identities, Peripheral Theologies: Expanding Conversations in Analytic Theology, edited by Michelle Panchuk and Michael Rea (Oxford University Press). 3-6-2019 Draft, please do not cite without prior permission.

defines its flourishing in the Edenic ideal of Genesis is that of human individuals in community mirroring, representing or "imaging" God's own care for the created order by cooperatively caring for it. Essentially constitutive of our flourishing qua images, therefore, is our capacity to mediate divine care in our mutually dependent relations with one another, and in our cooperative nurture of land and non-human life. The human "Fall" interrupts not only human life but introduces a breech in the created order, one that involves a devolution and aberration of our relationship with God. This broken relationship is evidenced primarily by our failure of mutual dependence on and cooperation with one another and our consequent abuse of one another, land, and nonhuman creatures.

The principal human expression of this breech with God and nature, in Christian Scripture, is social and political enmity, oppression and violence, which is equated with an alienation from divine judgment and a moral "pollution" of land. God's work of redemption on that story is therefore a work primarily aimed at the restoration of a renewed form of human community freed from these material distortions of human life. The vision of that freedom is just the "kingdom of God" - a form of divine ordering of human social and political life within which human mediation of divine caretaking for one another and non-human creation is recovered. That vocation is what is embodied by God's redemption of Israel and ordering of its social and political life by the promise of the Law, which had as its intended end the recovery of the Edenic ideal, and fulfilled in the life, death and resurrection of Jesus, through whom God has recovered that ideal. The church, Christians have held, is the community that bears witness to the realization of God's social and political ideal for humanity in the present as a kind of "preview" of the eschatological completion of that ideal that awaits us in the age to come. Christian social identity and practice is essentially oriented by this "already" and "not yet" of divine redemption for which God's victory over sin and death has already been partially and imperfectly realized in Christ's present presence and agency for the church while also not yet consummated in the restoration of the world that awaits Christ's return.

On this picture eudaimonia given in a Christian story of creation and redemption, we ought to place a high relative importance in our theological theorizing about the subject matter of our present and future liberation from social and political oppression. The significance of social and political oppression in this life for a Christian eudaimonism is a function of its significance in the "already" of this story - the mission of the church to enact a present-day preview of the form of communal life it awaits in the age to come. Accordingly, to justify LT's privileging of liberation from social and political oppression in this life as a substantive all things considered requirement for good theology, liberation theologians need only show that this mission centrally involves attention to social and political conditions of liberation and oppression. Thus Cone, for example, argues that the rescue of Israel from slavery in Egypt and Jesus' proclamation of God's rescue of the poor and marginalized in the Gospels are not incidental to the Christian Gospel, but partially constitutive of it. ${ }^{45}$

${ }^{45}$ Cone, A Black Theology of Liberation, 2-4. 
Forthcoming in Marginalized Identities, Peripheral Theologies: Expanding Conversations in Analytic Theology, edited by Michelle Panchuk and Michael Rea (Oxford University Press). 3-6-2019 Draft, please do not cite without prior permission.

Other liberation theologians similarly point to Paul's proclamation of the reconciliation of all people in Christ, and the overcoming of the enmity of ethnic, economic, gendered, and sexual identities evinced by the ruling powers of the present age as points to be plotted along the same trajectory (in, e.g., Gal. 3:28). As Paul puts it in Galatians, it is "for freedom that Christ set us free" (Gal. 5:1). Many also rely on the prophetic tradition of the Old Testament witness, which demands what Latin American liberation theologians identify as a "preferential option for the poor," 46 and condemns nationalistic fantasies, even when they are Israelite. While Israelite and Christian communities across the Scriptural witness do not always properly proclaim or live up to the conceptual or material requirements of the liberative trajectory set by Scripture itself, that trajectory is what God intends for the Church in its continuation of Jesus's proclamation of "good news" to the poor, the marginalized, the victims of injustice at the hands of worldly systems of power.

Suppose that the liberation theologian's construal of Christian eudaimonism is right. That would mean not just that Christians have a unique interest in identifying those who suffer oppression in this life and articulating the hope of freedom as realizable through the present victory of Christ in and through Christian community, but also that this vocation is of central importance to Christian identity and practice per se. Thus, while it could be that there are other ways in which the practice of theological theorizing might contribute to human flourishing on a Christian conception of what that means-our theorizing could very well be an expression of worship, contemplative prayer, or cognitive intimacy with the Lord ${ }^{47}$ - these goods might be overridden or outweighed by theorizing that serves the interests of the oppressed. In the absence of theorizing in conformity to the "Great Inversion" of Jesus that exalts the lowly and humbles the pride of the powerful, Christian theological theorizing might be a form of worship on par with the Temple sacrifices of those who refuse to do justice: a stench in the divine nostrils (Amos 5:21-27).

So on the appropriate background picture of human flourishing Christians might regard liberation from social and political oppression to be a "substantive" criterion for good theology, a normative constraint on theological theory choice that prefers theories that serve the interest of liberation over those that don't. But this does not require liberation theologians to hold that we ought not theorize about matters that seem only distantly related to the identification of the oppressed or a specification of the conditions for proclaiming and enacting as God's people Christ's liberation for them. Rather, it just that any non-liberative subject matter of our theorizing faces a kind of justificatory burden about what makes its putative deliverances worth knowing. Whether God in fact possesses any of the attributes classically ascribed to divinity, whether libertarian

${ }^{46}$ See Singh, 551-563; Zoë Bennett, “"Action is the life of all': the praxis-based epistemology of liberation theology," in Cambridge Companion to Liberation Theology, edited by Christopher Rowland (New York: Cambridge University Press, 2007), 39-54; Gerald West, "The Bible and the poor: a new way of doing theology," ibid., 159-182.

47 See Marilyn McCord Adams, "What's Wrong with the Ontotheological Error?" Journal of Analytic Theology 2 (May, 2014): 1-12; Paul J. Griffiths, The Practice of Catholic Theology (Washington, D.C.: The Catholic University of America Press, 2016), 24-26. 
Forthcoming in Marginalized Identities, Peripheral Theologies: Expanding Conversations in Analytic Theology, edited by Michelle Panchuk and Michael Rea (Oxford University Press). 3-6-2019 Draft, please do not cite without prior permission.

freedom exists, etc. may well turn out to be of great importance in light of a Christian conception of human flourishing. Proclaiming good news to the poor on a Christian conception of what that means may require a proper understanding of the asymmetric divine accessing relations between the human and divine natures of Jesus. ${ }^{48}$ But according to LT, much AT mistakenly proceeds simply as if the all things considered importance of any such projects is either self-evident, or immaterial to the permissibility of pursuing them.

If Christian theologians ought to prefer to offer theories about God and God's relation to the world that appropriately reflect the central eudaimonistic importance of God's liberating activity in the world, then it would be practically incoherent or selfdefeating to adopt a strategy of theorizing that runs contrary to God's liberating activity in the world. It is something like taking up the game of chess with a strategy-whether out of refusal or ignorance - that undermines the norm that defines the goal and purpose of playing the game in the first place. While there might be many possible ways that such an ignorance or refusal might be realized, there is a wide range of ways that are entirely consistent with a conformity to the rules of permissible movement for each piece, such as, e.g., trying to lose each of one's pieces as quickly as possible. Likewise, there are potentially many ways that one might fail or refuse to do Christian theology in conformity to the non-epistemic goods internal to it that guide theological theorizing, while nevertheless being faithfully guided by its epistemic goods. It is in virtue of a recognition of this fact that LT places not only a substantive but also a methodological constraint on Christian theology. Miranda Fricker highlights two ways that social and political oppression might impose itself on the practice of offering true explanatory theories that are especially relevant for Christian theology as construed by LT. First, she emphasizes the intuitive idea, grounded in Marx but developed more recently especially by Lukacs, that

a life led at the sharp edge of any given set of power relations provides the critical understanding (of the social world, in the first instance) where a life cushioned by the possession of power does not... [S]ocial identity and power relations...may influence epistemic access to the world. ${ }^{49}$

If we ought to be guided in our theorizing about God and God's relation to the world by our eudaimonistic interest in the comparative importance of God's liberating activity for the oppressed, then our ability to evaluate or assess the significance of our explanatory theories for a Christian liberative ambition will depend on our epistemic access to the relevant facts about liberation for the oppressed. We will need to know, for example, what sorts of oppression human suffer, where and how the effects of that oppression is registered in our cognitive and practical lives, and how central loci of theological interest

48 Thomas V. Morris, The Logic of God Incarnate (Ithaca: Cornell University Press, 1986), 106.

${ }^{49}$ Miranda Fricker, "Feminism in Epistemology: Pluralism without Postmodernism," in The Cambridge Companion to Feminism in Philosophy, edited by Miranda Fricker and Jennifer Hornsby (New York: Cambridge University Press, 2000), 147. See also Sandra Harding, Whose Science? Whose Knowledge? Thinking from Women's Lives (Ithaca, NY: Cornell University Press, 1991). 
Forthcoming in Marginalized Identities, Peripheral Theologies: Expanding Conversations in Analytic Theology, edited by Michelle Panchuk and Michael Rea (Oxford University Press). 3-6-2019 Draft, please do not cite without prior permission.

are connected to God's liberating activity as it is, e.g. grounded in the divine nature, enacted in God's creation, providence, election, incarnation, and manifest in the life of the Church. But as Fricker notes, epistemic access to facts such as these is not evenly distributed - not everyone is in an equally good position to identify or evaluate them.

Whatever else it might mean to belong to an oppressed group as a woman, a sexual minority, a person of color, a person with a disability, a person of a lower socioeconomic class, or some intersection of these, it is to occupy a particular kind of social position, what Harding calls " "nodes' of historically specific social practices and social meanings that mediate when and how suffering occurs for such socially constructed persons." ${ }^{50}$ Harding explains the kind of relative advantage and disadvantage of epistemic access to the relevant social and facts about oppression in terms of the non-epistemic interests that affect our capacities to notice and attend to those facts. Thus "members of oppressed groups have fewer interests in ignorance about the social order and fewer reasons to invest in maintaining or justifying the status quo than do dominant groups." 51 The flip side of this is that those belonging to privileged groups who benefit from the material disadvantages of oppressed groups are very strongly prudentially motivated to maintain a kind of insensitivity to the relevant facts that would threaten their relative advantages.

Thus, for example, in speaking about racial identity, Charles Mills has famously drawn our attention to the "cognitive and moral economy psychically required for conquest, colonization, and enslavement," as a kind of "consensual hallucination" that "precludes self-transparency and genuine understanding of all social realities." 52 The infrastructure of social meanings and relations constitutive of racial identity, Mills argues, has systematically distorting cognitive effects on the racially privileged (i.e., whites), which include "processes of cognition, individual and social" including "perception, conception, memory testimony, and motivational group interest." 53 "Oppressors," Cone says, "never like to hear the truth in a socio-political context defined by their lies." 54 Those non-whites who are oppressed precisely by this consensual or structurally reinforced ignorance of white social position, on the other hand, enjoy a kind of privileged access to precisely what whites in virtue of their social position miss. Commenting on James Weldon Johnson remark that, "colored people of this country know and understand the white people better than the white people know and understand them," Mills observes that

${ }^{50}$ Harding, 122. There are important questions about what socially constructed kinds are (e.g., whether or not they are a species of natural kind, objective types, or what, as well as how particular group kinds should be analyzed), and whether or not social identities are reducible to social positions (as, e.g., Haslanger sometimes seems to suggest), but we needn't pronounce on any of those ontological questions for the epistemic consideration I'm interested in here.

${ }^{51}$ Harding, 126.

${ }^{52}$ Charles Mills, The Racial Contract (Ithaca, NY: Cornell University Press, 1997), 18-19.

${ }^{53}$ Mills, "White Ignorance," in Race and Epistemologies of Ignorance, edites by Shannon Sullivan and Nancey Tuana (New York: SUNY Press, 2007), 23-33.

${ }^{54}$ Cone, A Black Theology of Liberation, xvi. 
Forthcoming in Marginalized Identities, Peripheral Theologies: Expanding Conversations in Analytic Theology, edited by Michelle Panchuk and Michael Rea (Oxford University Press). 3-6-2019 Draft, please do not cite without prior permission.

Often for their very survival, blacks have been forced to become lay anthropologists, studying the strange culture, customs, and mind-set of the "white tribe" that has such frightening power over them, that in certain time periods can even determine their life or death on a whim. ${ }^{55}$

But while there is therefore some sense in which oppressed social and political identities have a privileged mode of epistemic access to that which Christians ought to deem matters of central theological importance, Fricker further points out that, secondly, "social identity may constrain participation in epistemic practices - practices of asserting, denying, telling, asking, giving reasons, etc." 56 On the one hand, in seeking to provide true explanatory theories of any sort one must necessarily engage in such practices, but on the other hand those practices are

in large measure interactive, so that a person's full participation in them depends on certain reciprocating background attitudes on the part of fellow participants - attitudes which, for instance, provide for the appropriate distributions of trust and of credibility. If relations of gender, class, or race cause distortion in these background attitudes, then social identity and power have intervened in a manner that can be the concern not merely of the sociologist of knowledge, but of the epistemologist. ${ }^{57}$

For theological inquiry in particular, the two factors that Fricker identifies above work in tandem, so that those who are best positioned epistemically to identify the sites of theological inquiry that Christian theologians have most reason to prefer, all things considered, are the worst positioned to shape the practice of theological inquiry. The kind of epistemic "privilege" associated with identifying oppressive social arrangements and forms of agency enjoyed by those of disadvantaged social classes also imposes corresponding epistemic deficits, such as their acceptance as credible sources of testimonial knowledge or interpretive competence. ${ }^{58}$ In addition to the potential inaccessibility of these epistemic goods, belonging outside a dominant social class can also bring with it disadvantages in the ability to identify and access the prudential goods required to prosecute the kind of theological inquiry consistent with a Christian eudaimonistic interest in that practice. These considerations go a long way towards explaining why it is that the theological market-share of LT tends to be insulated from significant engagement with modes of theological inquiry that place comparatively less importance on matters of social and political oppression. As Cone puts it

White theologians wanted me to debate with them about the question of whether 'black theology' was real theology, using their criteria to decide the issue. With clever theological sophistication, white theologians defined

${ }^{55}$ Mills, 17-18.

${ }^{56}$ Fricker, 147.

57 Ibid.

${ }^{58}$ For a detailed account of testimonial and hermeneutical injustice as species of epistemic injustice, see Fricker, Epistemic Injustice (New York: Oxford University Press, 2007). 
Forthcoming in Marginalized Identities, Peripheral Theologies: Expanding Conversations in Analytic Theology, edited by Michelle Panchuk and Michael Rea (Oxford University Press). 3-6-2019 Draft, please do not cite without prior permission.

the discipline of theology ... [as] unrelated to the problem of slavery and racism. Using a white definition of theology, I knew there was no way I could win the debate . . . Racism is a disease that perverts one's moral sensitivity and distorts the intellect ... They who are responsible for the evil of racism also want to tell its victims whether bigotry is a legitimate subject matter of systematic theology... Why then should I spend my intellectual energy answering their questions, as if their experience were the only source from which theology derives its questions?"59

Cone here reflects on just the situation of asymmetric distribution in epistemic and prudential advantages and disadvantages that Fricker analyzes - one that accords the most significant regulative control over theological knowledge-seeking to those who occupy epistemic positions least well-suited to discern and evaluate the eudaimonistic significance of oppression that is partially constitutive of the practice of Christian theology. But even where the more traditional and orthodox research programs of theology adopt a more epistemically permissive attitude toward proponents of LT than the sort Cone describes, they are often subject to what José Medina (riffing on Hilary Putnam $)^{60}$ calls a "social division of cognitive laziness"- - a form of culpable ignorance that is justified by a kind of buck-passing under the banner of a disciplinary division of labor. $^{61}$

As in the substance of theological inquiry, so too for its mode, liberation theologians have described this dynamic as an epistemic consequence of the "great inversion" of God's liberating activity. In the Gospels we find Jesus emphasizing that stakeholders in various worldly systems of oppressive power, including religious stakeholders, are those who fail to properly discern the theologically trivial from the weighty, while it is revealed and accessible to those occupying the vantage of the oppressed. As St. Paul memorably puts it:

the message of the cross is foolishness to those who are perishing, but to us who are being saved it is the power of God. . Where is the wise person? Where is the teacher of the law? Where is the philosopher of this age? Has not God made foolish the wisdom of the world? For since in the wisdom of God the world through its wisdom did not know him, God was pleased through the foolishness of what was preached to save those who believe . . Brothers and sisters, think of what you were when you were called. Not many of you were wise by human standards; not many were influential; not many were of noble birth. But God chose the foolish things of the world to shame the wise; God chose the weak things of the world to shame the strong. God chose the lowly things of this world and the despised things-

${ }^{59}$ Cone, xvii-xviii.

${ }^{60}$ Hilary Putnam, “Meaning and Reference,” Journal of Philosophy 70/19 (1973): 699-711.

${ }^{61}$ José Medina, The Epistemology of Resistance (New York: Oxford University Press, 2013), 145 147. For a particular analysis of the way this works itself out in philosophy, see Lucius T. Outlaw, "Social Ordering and the Systematic Production of Ignorance," in Race and Epistemologies of Ignorance, 197-211. 
Forthcoming in Marginalized Identities, Peripheral Theologies: Expanding Conversations in Analytic Theology, edited by Michelle Panchuk and Michael Rea (Oxford University Press). 3-6-2019 Draft, please do not cite without prior permission.

and the things that are not - to nullify the things that are, so that no one may boast before him. ${ }^{62}$

The unique epistemic access to theological knowledge afforded by one's oppressed social status is just the sort of fact that Fricker identifies and Cone incorporates into his approach to theology that gives black voices a privileged methodological place. M. Shawn Copeland's womanist theology identifies this as a kind of "critical cognitive praxis" that expresses "subjugated knowledge" 63 constitutive of an "ethics of thinking." Copeland develops the idea of a theological "canon" that accords with St. Paul's analysis of Christian theological knowledge-seeking - such an alternative canon of those socially and politically deemed lowly is a traditioned expression of a particular kind of mind that Paul identifies with the mind of Christ. "It leads and trains a mind in an appropriation of a tradition of epistemic, aesthetic, moral and cultural decisions, priorities, and desires.",64 Overcoming the coercive epistemic silencing, dismissal and privilege-blindness of nonliberation theologians who represent socially and politically dominant identities requires a retrieval of such a canon that represents the interests of the socially and politically oppressed across time and space. ${ }^{65}$

\section{Christian AT as LT}

Despite the considerable and impressive theological market share that AT has acquired in contemporary academic theology, it has by and large failed to engage in or with theologies of liberation. If the case for LT I've made above is right, then Christian theologians who have become enthusiastic about AT have neglected the "one thing needful" in that enthusiasm. Namely they have not reckoned with a meta-theological case for LT, according to which any instance of good theology will be an instance of theology substantively and methodologically committed to the cognitive and practical importance of serving the interests of the socially and politically oppressed. My defense of LT aims in the first place to be an instance of AT, insofar as it conforms to the ambitions of offering a true explanatory theory falling outside the natural sciences, illuminates a normative constraint on the scope and nature of our knowledge of the world, and does both in a manner that does not obviously violate any of Rea's stylistic prescriptions P1-P5. But even if it fails as a defense of LT, and as such fails to prompt any analytic theologians to take up a theological commitment to LT and produce

${ }^{62}$ I Cor. 1:18-30, NIV

${ }^{63}$ M. Shawn Copeland, "A Thinking Margin: The Womanist Movement as Critical Cognitive Praxis," in Deeper Shades of Purple: womanism in religion and society, edited by Stacey M. FloydThomas (New York: NYU Press, 2006), 227-228. Copeland's "subjugated knowledge" approximates Harding's conception of epistemic advantage of the oppressed, Mills's conception of survivalist anthropology, and what Rowan Williams calls the "intelligence of the victim," in Christ on Trial: How the Gospel Unsettles our Judgment (Grand Rapids, MI: Eerdmans, 2003), 45-46: "not because it is good or holy in itself to be a victim, far from it, but because looking at the world from the point of view of those excluded by worldly systems of power frees us from the need always to be securing our own power at all costs" (46).

\footnotetext{
${ }^{64}$ Copeland, 231.
}

${ }^{65}$ Ibid., 232. 
Forthcoming in Marginalized Identities, Peripheral Theologies: Expanding Conversations in Analytic Theology, edited by Michelle Panchuk and Michael Rea (Oxford University Press). 3-6-2019 Draft, please do not cite without prior permission.

exemplary instances of it, the argument might serve to raise a secondary question that I find isn't adequately addressed in the AT literature: namely, what should we think it is that makes theology in general, and AT in particular, worth doing? Why should we be granted the requisite space, time, money, and material and intellectual infrastructure to do it? LT may not be the only viable answer, but any attractiveness it has depends on seeing the pressing significance of the question.

So suppose that a large proportion of particularly Christian stakeholders in AT do recognize the pressing importance of the question and moreover that it prompts us toward the development of a research program in analytic theologies of liberation. What sorts of revisions to the present state of AT would that require? Arguably, it would require a significant revision in the content, the constituency, and the canon of theology as standardly construed in AT. As it presently exists, analytic theologians have not taken up theological topics with any demonstrably liberative ambitions with respect to the most important forms of social and political oppression that contribute to human misery in our lives here below and in via.

To engage AT as LT would require us to remedy this in the subject matter we choose to treat and the questions we are seeking to answer by way of our treatments. That implies no shift away from theological metaphysics or epistemology toward ethics in particular, only a shift in perspective about issues and questions in theological metaphysics and epistemology are made especially salient from the standpoint of the oppressed. A shift of that sort, however, would also require a corresponding shift in the constituency of AT, which at this moment remains predominantly made up of those socially and politically dominant groups and as such remains subject to the systematic distortions in the distribution and significance of epistemic and non-epistemic goods that order their knowledge-seeking. Finally, the inclusion of socially oppressed groups, while necessary, is insufficient for bringing about the requisite move toward LT apart from representing a corresponding change in the sources or canons of theological reflection that shape our aims and interests in the practice of theology. ${ }^{66}$

${ }^{66}$ As Linda Martín Alcoff points out, it is always possible that "members of oppressed groups also have specific reasons to maintain their own ignorance about the social order... But such reasons... may be outweighed by the need to know the true reality of the social conditions within which one must survive." See her "Epistemologies of Ignorance: Three Types," in Race and Epistemologies of Ignorance, 43-44. 